\title{
Enterobacter pulveris sp. nov., isolated from fruit powder, infant formula and an infant formula production environment
}

\author{
Roger Stephan, ${ }^{1}$ Stefanie Van Trappen, ${ }^{2}$ IIse Cleenwerck, ${ }^{2}$ \\ Carol Iversen, ${ }^{1,3}$ Han Joosten, ${ }^{3}$ Paul De Vos ${ }^{2}$ and Angelika Lehner ${ }^{1}$ \\ ${ }^{1}$ Institute for Food Safety and Hygiene, Vetsuisse Faculty University of Zurich, Winterthurerstrasse \\ 272, 8057 Zurich, Switzerland \\ ${ }^{2}$ BCCM/LMG Bacteria Collection, Laboratorium voor Microbiologie, Universiteit Gent, \\ K. L. Ledeganckstraat 35, 9000 Gent, Belgium \\ ${ }^{3}$ Nestlé Research Centre, Nestec Ltd, Vers-chez-les-Blanc, Lausanne, Switzerland
}

Correspondence

Roger Stephan

stephanr@fsafety.uzh.ch
Recent studies on the isolation and identification of Enterobacter sakazakii have revealed the existence of novel Enterobacter species that persist in the same ecological niches. Iversen and others described unclassified members of the family Enterobacteriaceae isolated from dried food ingredients that formed divergent clusters using $16 \mathrm{~S}$ rRNA and $h$ sp60 gene sequence analysis (Iversen et al., 2004a), but which could be mistaken phenotypically for $E$. sakazakii (Iversen et al., 2004b). Lehner and others also described isolates from fruit powder that gave colony

Abbreviation: BPW, buffered peptone water.

The GenBank/EMBL/DDBJ accession numbers for the 16S rRNA gene sequences of strains 1160/04, 516/05, 601/05 ${ }^{\top}, E 441, E 443$ and E444 are DQ273686, DQ273682, DQ273684, EF472537, EF614996 and EF059835, respectively. The accession numbers for the rpoB gene sequences of strains 1160/04, 516/05, 601/05 ${ }^{\top}, E 441, E 443$ and E444 are EF486514, EF486513, EF486512, EF632062, EF632063 and EF632064, respectively.

A neighbour-joining tree of $16 \mathrm{~S}$ rRNA gene sequences showing the estimated phylogenetic relationships between Enterobacter pulveris sp. nov. and related genera within the family Enterobacteriaceae is available with the online version of this paper. morphologies on E. sakazakii isolation media that were typical for the target species, but the API 32E confirmation of these strains gave ambiguous results (Lehner et al., 2004). Subsequently, comparative analysis of $16 \mathrm{~S}$ rRNA gene sequences revealed that these isolates were clearly distinct from E. sakazakii with sequence similarities of $<97 \%$ (Lehner et al., 2006).

There is no evidence that the presence of these novel species in food products represents a health concern, but they do pose a challenge for the design of isolation methods for E. sakazakii, a micro-organism that is occasionally reported as an opportunistic pathogen and has been associated with infant formula (Lehner \& Stephan, 2004). These novel species share several typical characteristics with E. sakazakii, such as resistance to desiccation, production of a yellow pigment and constitutive metabolism of 5-bromo-4-chloro-3-indolyl- $\alpha$-D-glucopyranoside, which is a significant trait used in the differentiation of presumptive E. sakazakii colonies (Iversen et al., 2004b).

Recently, two groups from the fruit powder isolates have been described as novel species, Enterobacter helveticus and 
Enterobacter turicensis (Stephan et al., 2007). The characterization of a third group of strains, with representative isolates from fruit powder, infant formula and an infant formula production environment, is described in this study and it is concluded that these isolates represent another novel Enterobacter species.

Apple fruit powder $(150 \mathrm{~g})$ samples (spray-dried powder of $100 \%$ fruit pulp or vacuum-dried granules of fruit juice) were suspended in $1.35 \mathrm{l}$ buffered peptone water (BPW) and incubated for $24 \mathrm{~h}$ at $37^{\circ} \mathrm{C}$. Samples $(0.1 \mathrm{ml})$ of the BPW enrichment were subcultured in $9 \mathrm{ml}$ Enterobacteriaceae enrichment broth (BBL EE broth; Becton Dickinson) for $24 \mathrm{~h}$ at $37^{\circ} \mathrm{C}$ and subsequently plated on violet red bile glucose agar (Difco VRBG; Becton Dickinson) and chromogenic E. sakazakii agar (Oxoid CM1055). After incubation for $24 \mathrm{~h}$ at $37^{\circ} \mathrm{C}$, isolates 1160 / 04 (=LMG 24058=DSM 19146), 516/05 and 601/05 $\left(=\right.$ LMG $24057^{\mathrm{T}}=$ DSM $\left.19144^{\mathrm{T}}\right)$ were recovered as typical turquoise colonies from E. sakazakii agar. All strains produced yellow-pigmented colonies on tryptone soy agar (TSA) plates.

In addition to the isolates obtained from fruit powder, three further isolates have been obtained from infant formula [E441 (=LMG 24059=DSM 19145) and E443] and an infant formula production environment (E444) using the ISO/TS for E. sakazakii (Anonymous, 2006).

For morphological and physiological studies, strains were grown on BHI medium (Oxoid CM0225). Physiological studies were performed using API 32E and Biotype 100 tests with Biotype Medium 1, according to the instructions of the manufacturer (bioMérieux). Motility testing and indole and $\mathrm{H}_{2} \mathrm{~S}$ production were performed in SIM agar (BD) at $37^{\circ} \mathrm{C}$.

The six isolates consisted of facultatively anaerobic, motile, Gram-negative coccoid rods $(0.9-1.0 \times 1.5-3.0 \mu \mathrm{m})$. After $24 \mathrm{~h}$ aerobic incubation at $37{ }^{\circ} \mathrm{C}$ on sheep blood agar, colonies were non-haemolytic and yellow pigmented. Yellow pigmentation increased when colonies were exposed to light. All strains were negative or weakly positive for the oxidase reaction and were catalase-positive. The strains could grow at $10-44{ }^{\circ} \mathrm{C}$. The minimal $\mathrm{pH}$ for growth at $37{ }^{\circ} \mathrm{C}$ was pH 5.0 for all strains. Generally, the six strains had the same biochemical profile, but they gave variable results for the utilization of dulcitol, aesculin, putrescine, turanose, DL- $\alpha$-amino-n-butyrate, DL-glycerate, lactulose, maltitol, 1-O-methyl- $\alpha$-D-glucopyranoside and Ltartrate as sole sources of carbon (see Table 1 and species description).

Sequencing of the 16S rRNA genes was performed according to the protocol described by Lehner et al. (2006). The almost complete 16S rRNA gene sequences comprising 1220 (1160/ 04), $1317(516 / 05), 1325\left(601 / 05^{\mathrm{T}}\right), 1420$ (E441), 1412 (E443) and 1479 (E444) nucleotides were determined and aligned to 28000 almost full-length 16S rRNA gene sequences using the alignment tool of the ARB package (Ludwig et al., 2004). Alignments were refined by visual inspection. Analysis of the 16S rRNA gene sequences was performed using the distance-matrix tool and a phylogenetic tree was estimated using the neighbour-joining method

Table 1. Phenotypic characteristics that differentiate Enterobacter pulveris sp. nov. from related species of the genus Enterobacter

Species: 1, Enterobacter pulveris sp. nov. ( $n=6) ; 2$, E. turicensis; 3, E. helveticus; 4, E. sakazakii; 5, E. cowanii; 6, E. aerogenes; 7, E. radicincitans; 8, E. gergoviae; 9, E. asburiae; 10, E. kobei; 11, E. cloacae subsp. cloacae; 12, E. cloacae subsp. dissolvens; 13, E. hormaechei; 14, E. cancerogenus; 15, E. nimipressuralis; 16, E. amnigenus biovar 1; 17, E. amnigenus biovar 2; 18, E. intermedius; 19, E. ludwigii; 20, E. pyrinus. -, 0-10\% Positive; (-), 10$20 \%$ positive; $v$, 20-80 \% positive; ( +), 80-90\% positive; +, 90-100\% positive; ND, no data available. Data from this study and Hoffmann et al. (2005), Kämpfer et al. (2005), Farmer et al. (2007) and Stephan et al. (2007).

\begin{tabular}{|c|c|c|c|c|c|c|c|c|c|c|c|c|c|c|c|c|c|c|c|c|}
\hline Characteristic & 1 & 2 & 3 & 4 & 5 & 6 & 7 & 8 & 9 & 10 & 11 & 12 & 13 & 14 & 15 & 16 & 17 & 18 & 19 & 20 \\
\hline Voges-Proskauer test & - & - & - & + & + & + & + & + & - & + & + & + & + & + & + & + & + & + & + & $(+)$ \\
\hline Methyl red test & + & + & + & - & - & - & - & - & + & - & - & - & - & - & - & - & $\mathrm{V}$ & - & - & - \\
\hline $\begin{array}{l}\text { Ornithine } \\
\text { decarboxylation }\end{array}$ & - & - & - & + & ND & + & $\mathrm{ND}$ & + & + & $\mathrm{ND}$ & + & + & + & + & + & $\mathrm{V}$ & + & + & $\mathrm{ND}$ & + \\
\hline Arginine dihydrolase & - & - & - & + & ND & - & $\mathrm{ND}$ & - & $\mathrm{V}$ & ND & + & + & $\mathrm{v}$ & + & - & - & $\mathrm{V}$ & - & $\mathrm{ND}$ & - \\
\hline Motility & + & + & + & + & + & + & + & + & $(-)$ & $(+)$ & + & - & $\mathrm{v}$ & + & - & + & + & + & + & $\mathrm{V}$ \\
\hline Aesculin hydrolysis & + & + & + & + & + & + & + & + & + & - & $\mathrm{V}$ & + & - & + & + & + & + & + & $(-)$ & + \\
\hline \multicolumn{21}{|c|}{ Carbon source utilization: } \\
\hline Melibiose & + & + & + & + & + & + & - & + & - & + & + & + & $(-)$ & - & + & + & + & + & + & - \\
\hline Sucrose & + & - & - & + & + & + & + & + & + & + & + & + & + & - & - & + & - & $\mathrm{V}$ & + & + \\
\hline D-Arabitol & + & - & - & - & - & + & $\mathrm{ND}$ & + & - & - & $(-)$ & - & $(-)$ & - & - & - & - & - & - & - \\
\hline Mucate & + & + & + & - & + & + & $\mathrm{ND}$ & - & $\mathrm{V}$ & $\mathrm{V}$ & $\mathrm{V}$ & + & + & + & + & $\mathrm{V}$ & + & + & + & - \\
\hline D-Sorbitol & - & - & - & - & + & + & + & - & $(+)$ & + & + & + & $(-)$ & - & + & - & + & + & + & - \\
\hline L-Fucose & - & - & - & - & - & ND & $\mathrm{ND}$ & $\mathrm{V}$ & - & - & - & $\mathrm{V}$ & + & + & - & - & $\mathrm{ND}$ & $\mathrm{V}$ & $\mathrm{V}$ & - \\
\hline $\begin{array}{l}\text { 1-O-Methyl- } \alpha \text { - } \\
\text { galactopyranoside }\end{array}$ & + & + & + & + & + & ND & ND & + & $(+)$ & + & + & + & - & - & - & + & ND & + & + & - \\
\hline
\end{tabular}


combined with a Felsenstein correction, all included in the ARB package. The significance of branchings was evaluated by bootstrap analysis of 1000 replicates. Phylogenetic analyses were performed using distance matrix and the neighbourjoining dendrogram tool included in the ARB software package employing special data structures (PT-servers) derived from the ssu-rRNA database (ssu_jan04.arb).

The 16S rRNA gene sequences of isolates 1160/04, 516/05, $601 / 05^{\mathrm{T}}, \mathrm{E} 441, \mathrm{E} 443$ and E444 showed 99.3-99.5\% similarity to each other and formed a separate branch in the phylogenetic tree (see Supplementary Fig. S1 available in IJSEM Online). Based on the data of Stackebrandt \& Ebers (2006), this suggests that these strains may belong to the same species. The strains grouped most closely with a cluster containing E. helveticus LMG $23732^{\mathrm{T}}$ (GenBank accession no. DQ273688; 98.6-99.2\% sequence similarity), E. sakazakii DSM $4485^{\mathrm{T}}$ (AB004746; 96.8-97.3\% sequence similarity) and E. sakazakii ATCC 51329 (AY752937; 96.7$97.3 \%$ sequence similarity).

$16 \mathrm{~S}$ rRNA gene sequence analysis indicates that the strains belong to the family Enterobacteriaceae but, based on these results alone, they cannot unequivocally be allocated to a finer taxonomic level. Since $r p o B$ sequence analysis has been used successfully for species discrimination within the family Enterobacteriaceae (Mollet et al., 1997; Drancourt et al., 2001; Li et al., 2004; Kämpfer et al., 2005; Stephan et al., 2007), this approach was also used to determine the taxonomic position of the six strains. Total DNA was prepared according to the protocol of Niemann et al. (1997). The $r p o B$ gene was amplified and sequenced following the protocol of Mollet et al. (1997). Sequence assembly was performed by using the program AUTOASSEMBLER (Applied Biosystems). Phylogenetic analysis was performed using TREECON software (Van de Peer \& De Wachter, 1994) after including the consensus sequence in a CLUSTAL W alignment (Thompson et al., 1994) of rpoB sequences collected from the EMBL nucleotide sequence library. Evolutionary distances were calculated using the Jukes-Cantor evolutionary model and a tree was constructed using the neighbour-joining method. Bootstrap values (500 replicates) were also calculated.

The $r p o B$ sequences of the six isolates showed 99.6-100.0\% sequence similarity to each other, indicating that they probably belong to the same species. The highest $r p o B$ sequence similarities were obtained with $E$. helveticus LMG $23732^{\mathrm{T}} \quad(95.6-95.8 \%)$, Enterobacter radicincitans CIP $108468^{\mathrm{T}}(91.5-91.7 \%)$, E. turicensis LMG $23730^{\mathrm{T}}$ (91.3$91.6 \%$ ) and E. sakazakii LMG $5740^{\mathrm{T}}(91.2-91.5 \%)$. The phylogenetic branch formed by E. helveticus, E. turicensis, E. sakazakii, E. radicincitans, Enterobacter cowanii and the six novel strains was supported by a high bootstrap value (95\%) (Fig. 1), demonstrating that they belong to the genus Enterobacter, taking into account that when using only one protein coding gene, a possible genetic transfer cannot be excluded. The similarity values found with their nearest neighbours were rather low (89.4-95.8\%) compared with the intraspecies similarity range of $98-$ $100 \%$ found in the family Enterobacteriaceae (Mollet et al., 1997), thus confirming that these strains represent a novel species within this family.

To confirm finally that these strains represent an independent genomospecies within the genus Enterobacter, DNADNA hybridizations with three representative strains were performed. DNA was prepared according to the method of Wilson (1987) and hybridizations were carried out at $45{ }^{\circ} \mathrm{C}$ according to the microtitre plate technique described by Ezaki et al. (1989). The DNA relatedness percentages are the means of a minimum of four hybridizations. Reciprocal reactions (i.e. $\mathrm{A} \times \mathrm{B}$ and $\mathrm{B} \times \mathrm{A}$ ) were performed and the variation between them was within the acceptable limits of this method (Goris et al., 1998).

The DNA-DNA hybridization results revealed that the strains $1160 / 04,516 / 05$ and $601 / 05^{\mathrm{T}}$ show a very high DNA-DNA relatedness to each other (99-100\%), demonstrating that they belong to the same genomospecies. The DNA-DNA relatedness between strain $601 / 05^{\mathrm{T}}$ and $E$. helveticus LMG $23732^{\mathrm{T}}$ was $54 \%$, which is clearly below $70 \%$, the generally accepted limit for species delineation (Wayne et al., 1987). On the basis of these genotypic results, it is concluded that the six strains represent a novel genomic species.

The overall $\mathrm{G}+\mathrm{C}$ content was also determined for three strains according to the HPLC method (Mesbah et al., 1989) using the DNA prepared for DNA-DNA hybridizations. The values (means of three independent analyses of the same DNA sample) for $1160 / 04,516 / 05$ and $601 / 05^{\mathrm{T}}$ were $57.0,56.4$ and $57.0 \mathrm{~mol} \%$, respectively. These values are consistent with the DNA G $+\mathrm{C}$ contents of other members of the genus Enterobacter (Richard, 1984; Inoue et al., 2000).

The results of this polyphasic analysis support the recognition of a novel Enterobacter species, for which the name Enterobacter pulveris sp. nov. is proposed. Details on the physiological and biochemical characteristics of the novel species are given below. It can be clearly differentiated from its nearest neighbours by several properties, including the utilization of melibiose, sucrose, D-sorbitol, D-arabitol, mucate and 1-O-methyl- $\alpha$-galactopyranoside and the Voges-Proskauer reaction (see Table 1).

\section{Description of Enterobacter pulveris sp. nov.}

Enterobacter pulveris (pul've.ris. L. n. pulvis -eris dust, powder; L. gen. n. pulveris of powder).

Cells are Gram-negative coccoid rods that are facultatively anaerobic and motile. Cells are $0.9-1.0 \mu \mathrm{m}$ wide by $1.5-$ $3.0 \mu \mathrm{m}$ long and occur singly or in pairs. After $24 \mathrm{~h}$ aerobic incubation at $37{ }^{\circ} \mathrm{C}$ on TSA medium, colonies are yellow pigmented and convex. Catalase-positive and negative or weakly positive for oxidase. Colonies grow poorly at $10{ }^{\circ} \mathrm{C}$ (within 3 days), but well at $44{ }^{\circ} \mathrm{C}$. Negative for ornithine decarboxylase, malonate decarboxylase, urease, arginine 


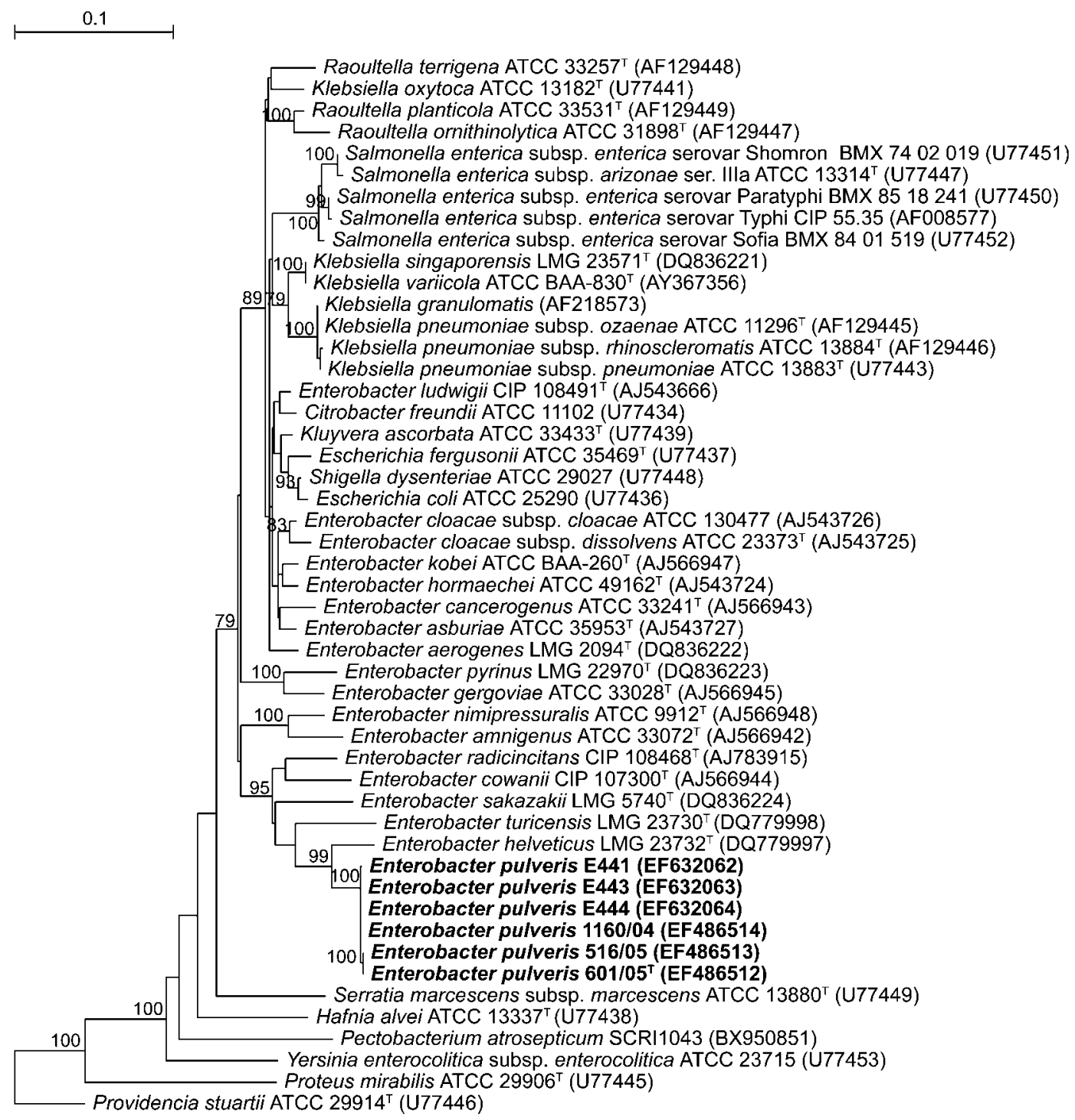

Fig. 1. Neighbour-joining tree comprising $r p o B$ gene sequences of Enterobacter pulveris sp. nov. and related members of the family Enterobacteriaceae. Bootstrap values (percentages of 500 replicates) of $>70 \%$ are shown. Bar, $0.1 \%$ nucleotide substitutions.

dihydrolase and lysine decarboxylase. Voges-Proskauer test, indole production and $\mathrm{H}_{2} \mathrm{~S}$ production are also negative. Acid is produced from galacturonate, D-mannitol, maltose, D-glucose, sucrose, D-arabitol, L-arabinose, trehalose, L-rhamnose and D-cellobiose. Acid is not produced from L-arabitol, 5-ketogluconate, adonitol, palatinose, inositol or D-sorbitol. The chromogenic substrates ONPG, 4-nitrophenyl- $\beta$-D-glucopyranoside, 4-nitrophenyl- $\beta$-D-galactopyranoside, 4-nitrophenyl- $\alpha$-D-glucopyranoside, 5-bromo-3-indoxyl-nonanoate (weak reaction), 4-nitrophenyl- $\alpha$-D-galactopyranoside and 4-nitrophenyl$\alpha$-D-maltopyranoside are hydrolysed. 4 -Nitrophenyl- $\beta$-Dglucuronide and L-aspartic acid 4-nitroanilide are not hydrolysed. Positive for utilization of $\alpha$-D-glucose, $\beta$-Dfructose, D-galactose, trehalose, D-mannose, melibiose, sucrose, raffinose, maltotriose, maltose, $\alpha$-lactose, 1-O-methyl- $\beta$-galactopyranoside, $\quad 1$-O-methyl- $\alpha$-galactopyranoside, D-cellobiose, $\beta$-gentiobiose, 1 -O-methyl- $\beta$-Dglucopyranoside, D-ribose, L-arabinose, D-xylose, $\alpha$-L-rhamnose, D-arabitol, glycerol, D-mannitol, D-saccharate, mucate, L-malate, cis-aconitate, trans-aconitate, D-glucuronate, D-galacturonate, 2-keto-D-gluconate, 5keto-D-gluconate, $\mathrm{N}$-acetyl-D-glucosamine, D-gluconate, protocatechuate, $p$-hydroxybenzoate, quinate, DL-lactate, fumarate, D-glucosamine, L-aspartate, L-glutamate, L-proline, $\mathrm{L}$-alanine and $\mathrm{L}$-serine. The following compounds are not utilized as sole sources of carbon: L-sorbose, $\alpha$-L-fucose, L-arabitol, xylitol, D-tagatose, myo-inositol, D-sorbitol, adonitol, hydroxyquinoline- $\beta$-glucuronide, i-erythritol, 3O-methyl-D-glucopyranose, D-tartrate, meso-tartrate, 
tricarballylate, L-tryptophan, phenylacetate, gentisate, $\mathrm{m}$ hydroxybenzoate, benzoate, 3-phenylpropionate, trigonelline, betaine, histamine, caprate, caprylate, L-histidine, glutarate, DL- $\alpha$-amino-n-valerate, ethanolamine, tryptamine, itaconate, DL- $\beta$-hydroxybutyrate, malonate, propionate, L-tyrosine and $\alpha$-ketoglutarate. Variable for utilization of dulcitol, aesculin, putrescine, turanose, DL$\alpha$-amino-n-butyrate, DL-glycerate, lactulose, maltitol, 1-Omethyl- $\alpha$-D-glucopyranoside and L-tartrate as sole sources of carbon. The DNA G $+C$ contents of strain $601 / 05^{\mathrm{T}}$ and representative strains $1160 / 04$ and 516/05 are 57.0, 56.4 and $57.0 \mathrm{~mol} \%$, respectively.

The type strain, $601 / 05^{\mathrm{T}}\left(=\mathrm{LMG} 24057^{\mathrm{T}}=\right.$ DSM $\left.19144^{\mathrm{T}}\right)$, was isolated from fruit powder.

\section{References}

Anonymous (2006). ISO/TS 22964:2006 Milk and Milk Products Detection of Enterobacter sakazakii, IDF/RM 210. Geneva, Switzerland: ISO.

Drancourt, M., Bollet, C., Carta, A. \& Rousselier, P. (2001). Phylogenetic analyses of Klebsiella species delineate Klebsiella and Raoultella gen. nov., with description of Raoultella ornithinolytica comb. nov., Raoultella terrigena comb. nov. and Raoultella planticola comb. nov. Int J Syst Evol Microbiol 51, 925-932.

Ezaki, T., Hashimoto, Y. \& Yabuuchi, E. (1989). Fluorometric deoxyribonucleic acid-deoxyribonucleic acid hybridization in microdilution wells as an alternative to membrane filter hybridization in which radioisotopes are used to determine genetic relatedness among bacterial strains. Int J Syst Bacteriol 39, 224-229.

Farmer, J. J., III, Boatwright, K. D. \& Janda, J. M. (2007). Enterobacteriaceae: introduction and identification. In Manual of Clinical Microbiology, 9th edn, vol. 1, chapter 42, p. 649. Edited by J. H. Jorgensen. Washington, DC: American Society for Microbiology.

Goris, J., Suzuki, K., De Vos, P., Nakase, T. \& Kersters, K. (1998). Evaluation of a microplate DNA-DNA hybridization method compared with the initial renaturation method. Can J Microbiol 44, 1148-1153.

Hoffmann, H., Stindl, S., Ludwig, W., Stumpf, A., Mehlen, A., Heesemann, J., Monget, D., Schleifer, K. H. \& Roggenkamp, A. (2005). Reassignment of Enterobacter dissolvens to Enterobacter cloacae as E. cloacae subspecies dissolvens comb. nov. and emended description of Enterobacter asburiae and Enterobacter kobei. Syst Appl Microbiol 28, 196-205.

Inoue, K., Sugiyama, K., Kosako, Y., Sakazaki, R. \& Yamai, S. (2000). Enterobacter cowanii sp. nov., a new species of the Enterobacteriaceae. Curr Microbiol 41, 417-421.

Iversen, C., Waddington, M., On, S. L. \& Forsythe, S. (2004a). Identification and phylogeny of Enterobacter sakazakii relative to Enterobacter and Citrobacter species. J Clin Microbiol 42, 5368-5370.

Iversen, C., Druggan, P. \& Forsythe, S. J. (2004b). A selective differential medium for Enterobacter sakazakii, a preliminary study. Int J Food Microbiol 96, 133-139.
Kämpfer, P., Ruppel, S. \& Remus, R. (2005). Enterobacter radicincitans sp. nov., a plant growth promoting species of the family Enterobacteriaceae. Syst Appl Microbiol 28, 213-221.

Lehner, A. \& Stephan, R. (2004). Microbiological, epidemiological and food safety aspects of Enterobacter sakazakii. J Food Prot 67, 2850-2857.

Lehner, A., Tasara, T. \& Stephan, R. (2004). 16S rRNA gene based analysis of Enterobacter sakazakii strains from different sources and development of a PCR assay for identification. BMC Microbiol 4, 43.

Lehner, A., Nitzsche, S., Breeuwer, P., Diep, B., Thelen, K. \& Stephan, R. (2006). Comparison of two chromogenic media and evaluation of two molecular based identification systems for Enterobacter sakazakii detection. BMC Microbiol 6, 15.

Li, X., Zhang, D., Chen, F., Ma, J., Dong, Y. \& Zhang, L. (2004). Klebsiella singaporensis sp. nov., a novel isomaltulose-producing bacterium. Int J Syst Evol Microbiol 54, 2131-2136.

Ludwig, W., Strunk, O., Westram, R., Richter, L., Meier, H., Yadhukumar, Buchner, A., Lai, T., Steppi, S. \& other authors (2004). ARB: a software environment for sequence data. Nucleic Acids Res 32, 1363-1371.

Mesbah, M., Premachandran, U. \& Whitman, W. B. (1989). Precise measurement of the $\mathrm{G}+\mathrm{C}$ content of deoxyribonucleic acid by highperformance liquid chromatography. Int J Syst Bacteriol 39, 159-167.

Mollet, C., Drancourt, M. \& Raoult, D. (1997). $r p o B$ sequence analysis as a novel basis for bacterial identification. Mol Microbiol 26, 1005-1011.

Niemann, S., Puehler, A., Tichy, H. V., Simon, R. \& Selbitschka, W. (1997). Evaluation of the resolving power of three different DNA fingerprinting methods to discriminate among isolates of a natural Rhizobium meliloti population. J Appl Microbiol 82, 477-484.

Richard, C. (1984). Genus VI. Enterobacter Hormaeche and Edwards 1960. In Bergey's Manual of Systematic Bacteriology, vol. 1, pp. 465469. Edited by J. T. Staley, M. P. Bryant, N. Pfennig \& J. G. Holt. Baltimore: Williams \& Wilkins.

Stackebrandt, E. \& Ebers, J. (2006). Taxonomic parameters revisited: tarnished gold standards. Microbiol Today 33, 152-155.

Stephan, R., Van Trappen, S., Cleenwerck, I., Vancanneyt, M., De Vos, P. \& Lehner, A. (2007). Enterobacter turicensis, sp. nov. and Enterobacter helveticus, sp. nov., isolated from fruit powder. Int J Syst Evol Microbiol 57, 820-826.

Thompson, J. D., Higgins, D. G. \& Gibson, T. J. (1994). CLUSTAL W: improving the sensitivity of progressive multiple sequence alignment through sequence weighting, position-specific gap penalties and weight matrix choice. Nucleic Acids Res 22, 4673-4680.

Van de Peer, Y. \& De Wachter, R. (1994). TREECON for Windows: a software package for the construction and drawing of evolutionary trees for the Microsoft Windows environment. Comput Appl Biosci 10, 569-570.

Wayne, L. G., Brenner, D. J., Colwell, R. R., Grimont, P. A. D., Kandler, O., Krichevsky, M. I., Moore, L. H., Moore, W. E. C., Murray, R. G. E. \& other authors (1987). International Committee on Systematic Bacteriology. Report of the ad hoc committee on reconciliation of approaches to bacterial systematics. Int J Syst Bacteriol 37, 463-464.

Wilson, K. (1987). Preparation of genomic DNA from bacteria. In Current Protocols in Molecular Biology, pp. 2.4.1-2.4.5. Edited by F. M. Ausubel, R. Brent, R. E. Kingston, D. D. Moore, J. G. Seidman, J. A. Smith \& K. Struhl. New York: Green Publishing \& Wiley-Interscience. 